\title{
Analisa Shakemap dan Jenis Sesar Studi Kasus: Gempabumi Terasa Di Purworejo - Jawa Tengah
}

\author{
Nugroho Budi Wibowo*, Dian Susri Nurhaci \\ Badan Meteorologi Klimatologi dan Geofisika, Stasiun Geofisika Yogyakarta \\ JL. Wates km 8, Dusun Jitengan, Desa Balecatur, Kecamatan Gamping, Sleman, \\ D.I YogyakartaTelp (0274) 6498383 \\ *Email: nugrohobudiwibowo@gmail.com
}

\section{ABSTRACT}

Earthquake July 18, 2016 at 5:59:00 am occur on land $18 \mathrm{Km}$ Northwest Purworejo. The earthquake measuring 3.6SR at a depth of 13 kilometers and was felt in Purworejo I - II MMI. This study aims to analyze the earthquake affected based on shakemap analysis and determine the type of fault used the initial motion of $\mathrm{P}$ waves that recorded on seismograph. Shakemap analys is using shakemap application at BMKG servers based on the accelerographnetwork BMKG. Meanwhile, an analysis the type of fault using focal application with data input signals from the seismograph SeisComP3 system. The highest values of peak ground acceleration (PGA) recorded in BPBDKebumen's station is 0.5075 gal (EW component), 0.5018 gal (NS component) and 0.3538 gal (UD component). Model shakemap for Purworejo earthquake felt I SIG (I-II MMI) in Purworejo, Kebumen and Banjarnegara. The models of focal mechanism are the first nodal obtained strike 321, dip 33, rake 95, and the second nodal obtained strike 135, dip 57, rake 87. Based on the distribution model compression axis (up or T) and dilatation (down or P), the type of fault is reverse fault. The epicenter of the Purworejo earthquake correlated with the Rebung faultin Purworejo.

Keyword: Shakemap, Focal Mechanis m, PGA, Intensity, Earthquake, Fault.

\section{ABSTRAK}

Gempabumi 18 Juli 2016 pukul 05:59:00 WIB terjadi di darat 18 Km Barat Laut Purworejo. Gempabumi tersebut berkekuatan 3.6 SR dengan kedalaman $13 \mathrm{Km}$ dan dirasakan di Purworejo I - II MMI. Penelitian ini bertujuan untuk menganalisa daerah terdampak gempabumi Purworejo berdasarkan analisa shakemap dan mengetahui jenis sesar berdasarkan gerak awal gelombang $\mathrm{P}$ yang terekam pada seismograf. Analisa shakemap menggunakan aplikasi server shakemap BMKG Pusat berdasarkan data jaringan accelerograph. Sedangkan, analis a jenis sesar menggunakan aplikasi focal dengan input data sinyal seismograf dari sistem seis comp3. Nilai percepatan getaran tanah (PGA) pada gempabumi Purworejo tertinggi terekam pada stasiun BPBD Kebumen yaitu 0.5075 gal (komponen EW), 0.5018 gal (komponen NS) dan 0.3538 gal (komponen UD). Model shakemapmenunjukkan gempabumi Purworejo dirasakan I SIG (I-II MMI) di Purworejo, sebagian Kebumen dan Banjarnegara.Hasil model focal mechanism pada nodal 1 diperoleh strike 321, dip 33 dan rake 95, sedangkan nodal 2 diperoleh strike 135, dip 57 dan rake 87. Berdasarkan model distribusi sumbu kompresi (up atau T) dan dilatasi (down atau P), jenis sesar tersebut berupa sesar naik. Episenter gempabumi Purworejo berkorelasi dengan keberadaan Sesar Rebung di Purworejo.

Kata kunci: Shakemap, Focal Mechanism, PGA, Intensitas Gempabumi, Sesar. 


\section{PENDAHULUAN}

Kepulauan Indonesia terletak pada pertemuan tiga lempeng tektonik utama, yaitu lempeng IndoAustralia di bagian Selatan dan Barat, lempeng Eurasia di bagian Utara, dan lempeng Pasifik di bagian Timur ${ }^{[1]}$. Kondisi ini membuat Kepulauan Indonesia memiliki resiko terhadap bencana gempabumi. Purworejo merupakan Kabupaten di Provinsi Jawa Tengah yang memiliki potensi bencana gempabumi, baik gempabumi dengan episenter di laut maupun di darat. Gempabumi dengan episenter di laut diakibatkan oleh aktifitas subduksi, sedangkan gempabumi di darat diakibatkan oleh aktifitas sesar. Pada tanggal 18 Juli 2016 pukul 05:59:00 WIB terjadi gempabumi tektonik dengan pusat gempa di darat $18 \mathrm{Km}$ Barat Laut Purworejo. Gempabumi tersebut berkekuatan 3.6 SR dengan kedalaman $13 \mathrm{Km}$ dan dirasakan di Purworejo I - II MMI. Berdasarkan data seismisitas, Kabupaten Purworejo jarang sekali terjadi gempabumi dengan episenter di darat dan dirasakan. Hipotesis awal, gempabumi tersebut diakibatkan aktifitas sesar Rebung. Penelitian ini bertujuan untuk menganalisa daerah terdampak gempabumi Purworejo berdasarkan analisa shakemap dan mengetahui jenis sesar berdasarkan gerak awal gelombang $\mathrm{P}$ yang terekam pada seismograf. Pembuatan shakemap menggunakan aplikasi server shakemap BMKG Pusat berdasarkan data jaringan accelerograph. Sedangkan analisa jenis sesar menggunakan aplikasi focal dengan input data sinyal seismograf dari sistem seiscomp3.

\section{DASAR TEORI}

\section{Shakemap (Peta Tingkat Guncangan)}

Shakemap (Peta Tingkat Guncangan) merupakan peta yang menunjukkan besarnya guncangan gempabumi dalam satuan percepatan (gal). Input model shakemap merupakan data percepatan maksimum dari jaringan accelerograph yang terdapat pada BMKG. Pemodelan nilai percepatan tanah pada suatu titik $\left(\mathrm{x}^{*}, \mathrm{y}^{*}\right)$ menggunakan persamaan ${ }^{[5]}$ :

$$
\overline{\mathrm{Yry}}=\frac{\frac{Y_{G M P E, x y}}{\sigma 2 G M P E}+\sum_{i=1}^{n} \frac{Y o b s, x y, i}{\sigma^{2} o b s, x y, i}+\sum_{j=1}^{n} \frac{Y c o n v, x y, i}{\sigma^{2} \operatorname{con} v, x y, j^{\prime}}}{\frac{1}{\sigma 2 G M P E}+\sum_{i=1}^{n} \frac{1}{\sigma^{2} o b s, x y, i}+\sum_{j=1}^{n} \frac{1}{\sigma^{2} \operatorname{conv}, x y, j^{\prime}}}
$$

Dimana:

$Y_{G M P E, x y}$ dan $\sigma 2_{G M P E}$ : amplitudo dan perbedaaannya pada titik $\left(x,{ }^{*} \mathrm{y}^{*}\right)$ yang diperoleh dari model GMPE

Yobs, $x y, i$ : Amplitudo observasi yang diskalakan pada titik $\left(x,{ }^{*} \mathrm{y}^{*}\right)$

$\sigma^{2} o b s, x y, i \quad$ : Perbedaan yang berhubungan dengan nilai observasiipada titik $\left(x,{ }^{*} \mathrm{y}^{*}\right)$

$Y$ conv $, x y, i$ : Amplitudo yang telah diskalakan pada titik $\left(x,{ }^{*} \mathrm{y}^{*}\right)$

$\sigma^{2} \operatorname{conv}, x y, j$ : Perbedaan yang berhubungan dengan konversi observasi jpada titik $\left(x,{ }^{*} \mathrm{y}^{*}\right)$. 
Output model shakemap berupada data percepatan dan dikonversi dalam Skala Intensitas Gempabumi (SIG) BMKG, seperti pada tabel berikut.

Tabel 1. (color online) Kategori Skala Intensitas Gempabumi (SIG) BMKG, MMI dan PGA ${ }^{[4]}$

\begin{tabular}{|c|c|c|c|c|c|}
\hline $\begin{array}{l}\text { Skala } \\
\text { SIG } \\
\text { BMKG }\end{array}$ & Warna & $\begin{array}{l}\text { Deskripsi } \\
\text { Sederhana }\end{array}$ & Deskrispsi Rinci & $\begin{array}{c}\text { Skala } \\
\text { MMI }\end{array}$ & $\begin{array}{l}\text { PGA } \\
\text { (gal) }\end{array}$ \\
\hline I & Putih & $\begin{array}{l}\text { TIDAK } \\
\text { DIRASAKAN (Not } \\
\text { Felt) }\end{array}$ & $\begin{array}{l}\text { Tidak dirasakan atau dirasakan hanya oleh beberapa } \\
\text { orang tetapi terekam oleh alat. }\end{array}$ & I-II & $<2.9$ \\
\hline II & Hijau & $\begin{array}{l}\text { DIRASAKAN } \\
\text { (Felt) }\end{array}$ & $\begin{array}{l}\text { Dirasakan oleh orang banyak tetapi tidak } \\
\text { menimbulkan kerusakan. Benda-benda ringan yang } \\
\text { digantung bergoyang dan jendela kaca bergetar. }\end{array}$ & III-IV & $2.9-88$ \\
\hline III & Kuning & $\begin{array}{l}\text { KERUSAKAN } \\
\text { RINGAN (Slight } \\
\text { Damage) }\end{array}$ & $\begin{array}{l}\text { Bagian non struktur bangunan mengalami } \\
\text { kerusakan ringan, seperti retak rambut pada } \\
\text { dinding, genteng bergeser ke bawah dan sebagian } \\
\text { berjatuhan. }\end{array}$ & VI & $89-167$ \\
\hline IV & Jingga & $\begin{array}{l}\text { KERUSAKAN } \\
\text { SEDANG } \\
\text { (Moderate Damage) }\end{array}$ & $\begin{array}{l}\text { Banyak Retakan terjadi pada dinding bangunan } \\
\text { sederhana, sebagian roboh, kaca pecah. Sebagian } \\
\text { plester dinding lepas. Hampir sebagian besar } \\
\text { genteng bergeserke bawah atau jatuh. Struktur } \\
\text { bangunan mengalami kerusakan ringan sampai } \\
\text { sedang. }\end{array}$ & $\begin{array}{l}\text { VII- } \\
\text { VIII }\end{array}$ & $\begin{array}{l}168- \\
564\end{array}$ \\
\hline V & Merah & $\begin{array}{l}\text { KERUSAKAN } \\
\text { BERAT (Heavy } \\
\text { Damage) }\end{array}$ & $\begin{array}{l}\text { Sebagian besar dinding bangunan permanen roboh. } \\
\text { Struktur bangunan mengalami kerusakan berat. Rel } \\
\text { kereta api melengkung. }\end{array}$ & IX-XII & $>546$ \\
\hline
\end{tabular}

\section{Bola Fokus dan Diagram Mekanisme Sumber Gempabumi}

Bola fokus merupakan ilustrasi penjalaran gelombang yang berpusat pada sumber gempabumi. Bola fokus meliputi penjalaran gelombang seismik yang menjalar dari sumber gempabumi sampai ke stasiun penerima. Untuk menentukan titik pada suatu bola fokus yang memuat informasi polaritas gerakanpertama gelombang $\mathrm{P}$ (kompresi dan dilatasi) diperlukan koordinat sudut sinar

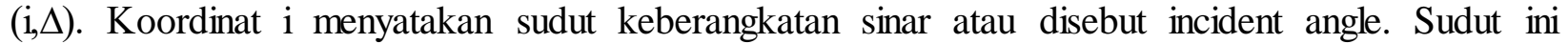
diukur dari arah vertikal sampai arah sinar, besarnya sudut idapat dihitung dengan persamaan [6]:

$$
\sin i=\frac{P V(h)}{(R-h)}
$$

Dengan:

$\mathrm{P} \quad$ : Parameter gelombang gempabumi /waktu kejadian detik (s).

$\mathrm{V}$ (h) : Kecepatan gelombang pada kedalaman $\mathrm{h}(\mathrm{m} / \mathrm{det})$.

$\mathrm{R} \quad$ : Jari-jari bumi (m).

h : Kedalaman sumber gempabumi (m)

Untuk menggambarkan distribusi polaritas gerakan pertama gelombang Psecara global, hiposenter diasumsikan sebagai bola dengan radius sangat kecil yang disebut bola fokus gempabumi. Bola fokus gempabumi yang didapatkan dari hasil analisa polaritas gerakanpertama gelombang Padalah dalam bentuk tiga dimensi, sehingga sulit untukdiinterpretasikan secara visual. Untuk itu perlu diproyeksikan ke dalam bentuk dua dimensi dengan cara membagi bola fokus gempa bumi menjadi 
dua bagian yang simetris memotong hiposenter, yaitu setengah bagian atas dan setengahbagian bawah. Proyeksi potongan bola pusat gempa bumi bagian bawah berupadiagram mekanisme sumber gempabumi (focal mechanism) dua dimensi. Dua garis nodal membagi diagram mekanisme sumber gempabumi ke dalam empat kuadran yang memisahkan daerah kompresi dan dilatasi. Dua bidang nodal tersebut adalah bidang patahan (fault plane) dan bidang bantu (auxilary plane) Sumbu $\mathrm{P}$ di kuadran dilatasi dan sumbu $\mathrm{T}$ di kuadran kompresi. Perpotongan antara dua garis nodal disebut sumbu N (null) yang merupakan arah Stressnol. Sumbu P, T, dan N ditentukan oleh sudut azimuth (diukur searah jarum jam dari arah utara) dan

Plunge (diukur ke bawah dari horizontal). Kedua sudut diukur dengan menggunakan kertas stereografis. Tekanan dan tarikan menunujukan arah gaya yang bekerja pada hiposenter, sedangkan kompresi dan dilatasi merupakan arah gerakan awal gelombang Pyang tercatat pada seismogram.

\section{METODE PENELITIAN}

\section{Pengolahan Shakemap (Peta Tingkat Guncangan)}

Shakemap dibuat menggunakan input stasiun accelerograph yang merekam sinyal gempa purworejo, yaitu stasiun WOJI (wonogiri), PCJI (Pacitan), KBJN (BPBD Kebumen), UGM (Wanagama), SCJI (Cilacap), SMRI (Semarang), dan SEKI (Staklim Semarang). Nilai percepatan tanah pada setiap stasiun dimodelkan untuk menghasilkan peta tingkat guncangan.

\section{Identifikasi Sesar dengan Polaritas Gelombang $\mathbf{P}$}

Parameter data yang digunakan adalah polaritas gelombang $\mathrm{P}$, jumlah dan nama stasiun yang mencatat gempabumi, koordinat (Lintang dan Bujur), dan kedalaman. Data polaritas gelombang $\mathrm{P}$ merupa sinyal kompresi (C) dan dilatasi (D) hasil rekaman sinyal gempabumi pada seismograf multistation. Data tersebut dapat diperoleh dari jaringan pengamatan gempabumi Seiscomp3 yang terdapat di Pusat Gempa Regional VII (Stasiun Geofisika Yogyakarta). Pembacan impuls awal gelombang $\mathrm{P}$ sinyal gempabumi dilakukan menggunakan aplikasi Seiscomp3. Gambar berikut menunjukkan proses picking gelombang P pada sistem Seiscomp3 [3].

\section{Model sesar berdasarkan program focal}

Program focal mechanism merupakan program pemodelan sesar berbasis MS-DOS dengan menggunakan input berupa parameter gempabumi, impuls awal gelombang $\mathrm{P}$ (kompresi atau dilatasi) dan data lokasi stasiun pencatat gempabumi. Model sesar yang dihasilkan dari program tersebut berupa dua model bidang nodal dengan parameter strike, dip dan rake. Interpretasi dilakukan pada dua model nodal untuk menentukan model nodal yang seusai dengan kondisi dilapangan. Interpretasi dilakukan dengan bantuan informasi data geologi regional diwilayah penelitian. 


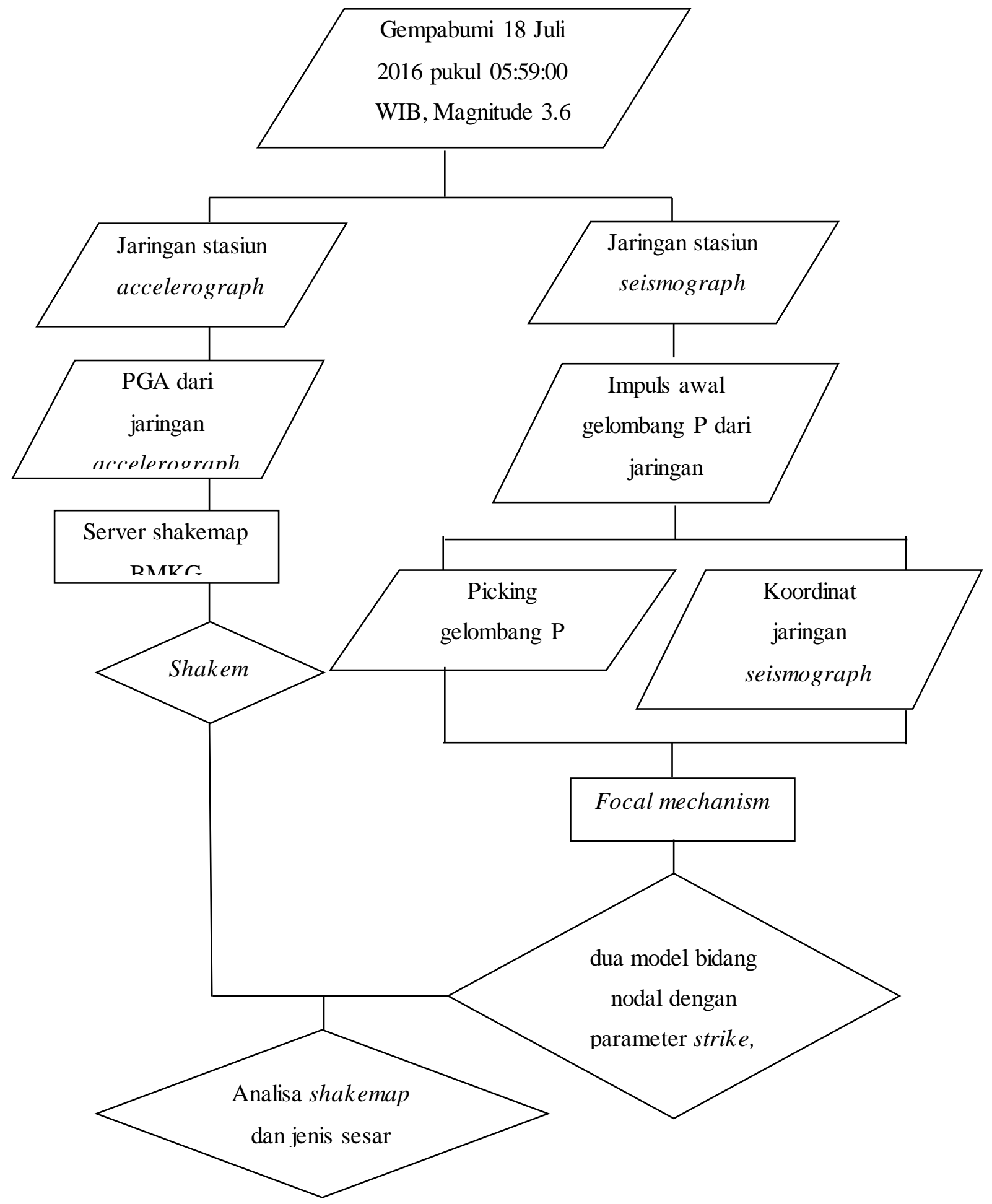

Gambar 1. Diagram Alir Penelitian 


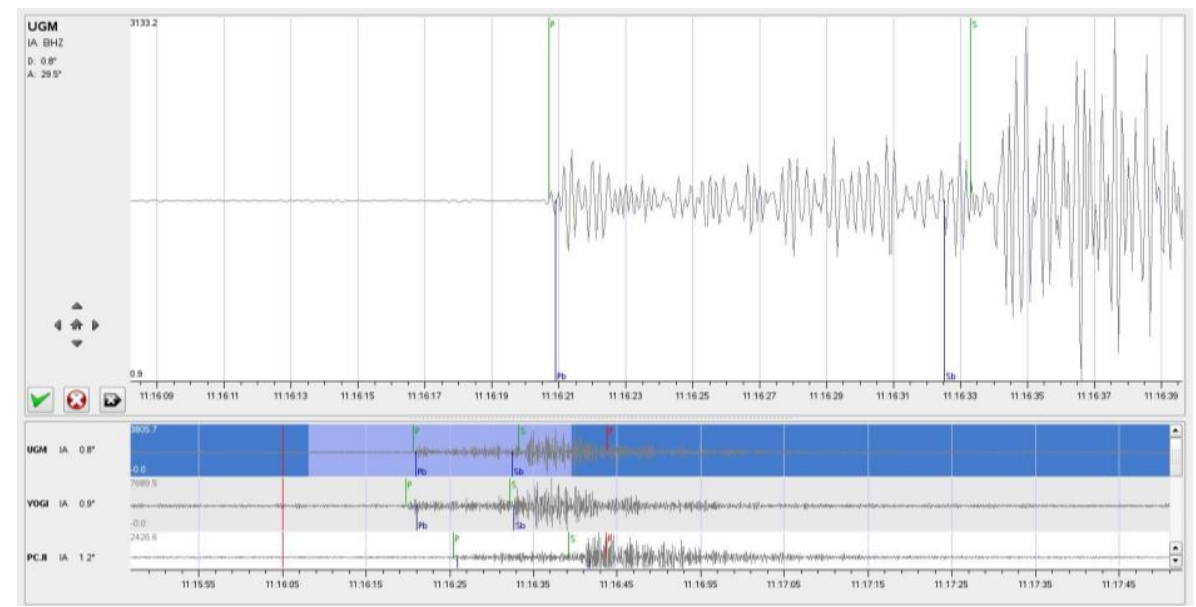

Gambar 2. (color online) Picking impuls awal gelombang P pada sistem Seiscomp3

\section{HASIL DAN PEMBAHASAN}

\section{Analisa Shakemap Gempabumi Purworejo}

Gempabumi Purworejo 18 Juli 2016 terekam pada beberapa stasiun accelerograph BMKG, gempabumi tersebut dirasakan oleh masyarakat di Purworejo dan sekitarnya. Stasiun accelerograph yang mencatat gempabumi tersebut antara lain: KBJN (Kebumen),UGM (Wonosari), SCJI (Cilacap), SMRI (Semarang), SEKI (Semarang), WOJI (Wonogiri) dan PCJI (Pacitan). Nilai percepatan getaran tanah (PGA) pada masing - masing stasiun disajikan pada Tabel 1.

Tabel 2. Nilai PGA, MMI, SIG dan Jarak Stasiun Accelerograph BMKG pada Gempabumi Purworejo

\begin{tabular}{ccccccccc}
\hline No & $\begin{array}{c}\text { ID } \\
\text { Stasiun }\end{array}$ & Stasiun & $\begin{array}{c}\text { Jarak } \\
(\mathbf{K m})\end{array}$ & MMI & SIG & $\begin{array}{c}\text { PGA-EW } \\
(\mathbf{g a l})\end{array}$ & $\begin{array}{c}\text { PGA-NS } \\
(\mathbf{g a l})\end{array}$ & PGA-UD (gal) \\
\hline 1 & WOJI & Wonogriri & 113.23 & I & I & 0.2548 & 0.2617 & 0.1186 \\
\hline 2 & PCJI & Pacitan & 152.48 & I & I & 0.0608 & 0.0725 & 0.1000 \\
\hline 3 & KBJN & $\begin{array}{c}\text { BPBD } \\
\text { Kebumen }\end{array}$ & 28.28 & II & I & 0.5075 & 0.5018 & 0.3538 \\
\hline 4 & UGM & Wanagama & 73.87 & I & I & 0.1215 & - & 0.0921 \\
\hline 5 & SCJI & Cilacap & 83.04 & I & I & 0.0392 & 0.0470 & 0.0323 \\
\hline 6 & SMRI & Semarang & 85.63 & I & I & 0.0637 & - & 0.0598 \\
\hline 7 & SEKI & $\begin{array}{c}\text { Staklim } \\
\text { Semarang }\end{array}$ & 87.01 & I & I & 0.0735 & 0.0098 & - \\
\hline
\end{tabular}

Sumber: Accelerograph, BMKG

Nilai percepatan getaran tanah (PGA) pada gempabumi Purworejo tertinggi terekam pada stasiun BPBD Kebumen yaitu 0.5075 gal (komponen EW), 0.5018 gal (komponen NS) dan 0.3538 gal (komponen UD). Stasiun tersebut merupakan stasiun terdekat dengan episenter, yaitu $28.28 \mathrm{Km}$. Namun, jarak tidak selalu berkorelasi positif (semakin jauh lokasi stasiun, semakin kecil nilai PGA). Stasiun Wonogiri memiliki nilai PGA yang cukup tinggi, yaitu 0.2548 gal (komponen EW), 0.2617 gal (komponen NS) dan 0.1186 gal (komponen UD). Faktor geologi setempat dapat 
memperngaruhi perbedaan nilai percepatan di suatu tempat, selain faktor jarak. Gambar 2, menunjukkan variasi nilai PGA pada masing - masing stasiun accelerograph.

Intensitas gempabumi (MMI) pada gempabumi Purworejo I - II MMI atau I SIG, yang berarti dirasakan oleh sedikit orang terutama pada bangunan bertingkat. Hasil tersebut merupakan hasil rekaman pada accelerograph, sedangkan informasi yang diperoleh Stasiun Geofisika Yogyakarta gempabumi purworejo dirasakan di Purworejo I - II MMI. Hal tersebut, sesuai dengan model shakemap yang dihasilkan. Model shakemap pada gambar 3, menunjukkan gempabumi tersebut dirasakan I SIG (I-II MMI) di Purworejo, sebagian Kebumen dan Banjarnegara.

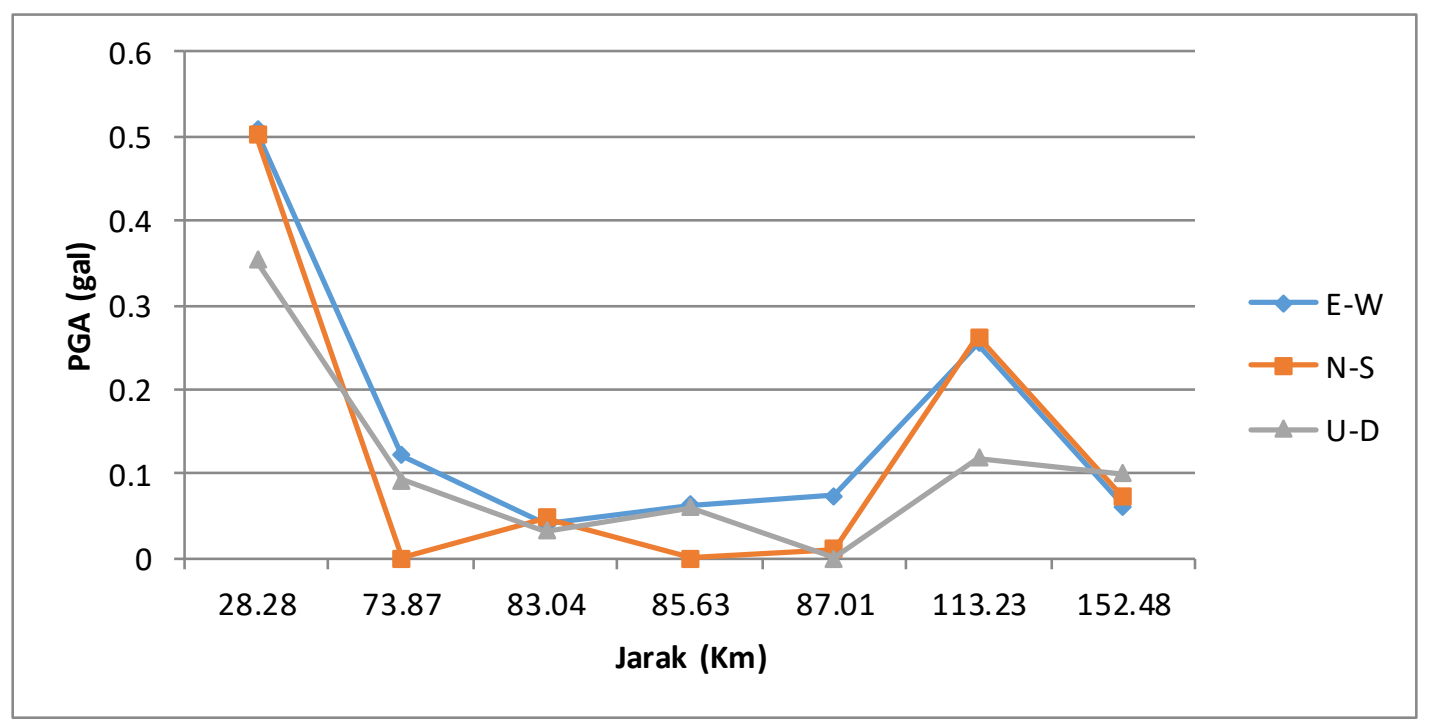

Gambar 3. (color online) Variasi nilai PGA berdasarkan jarak stasiun accelerogrpah 


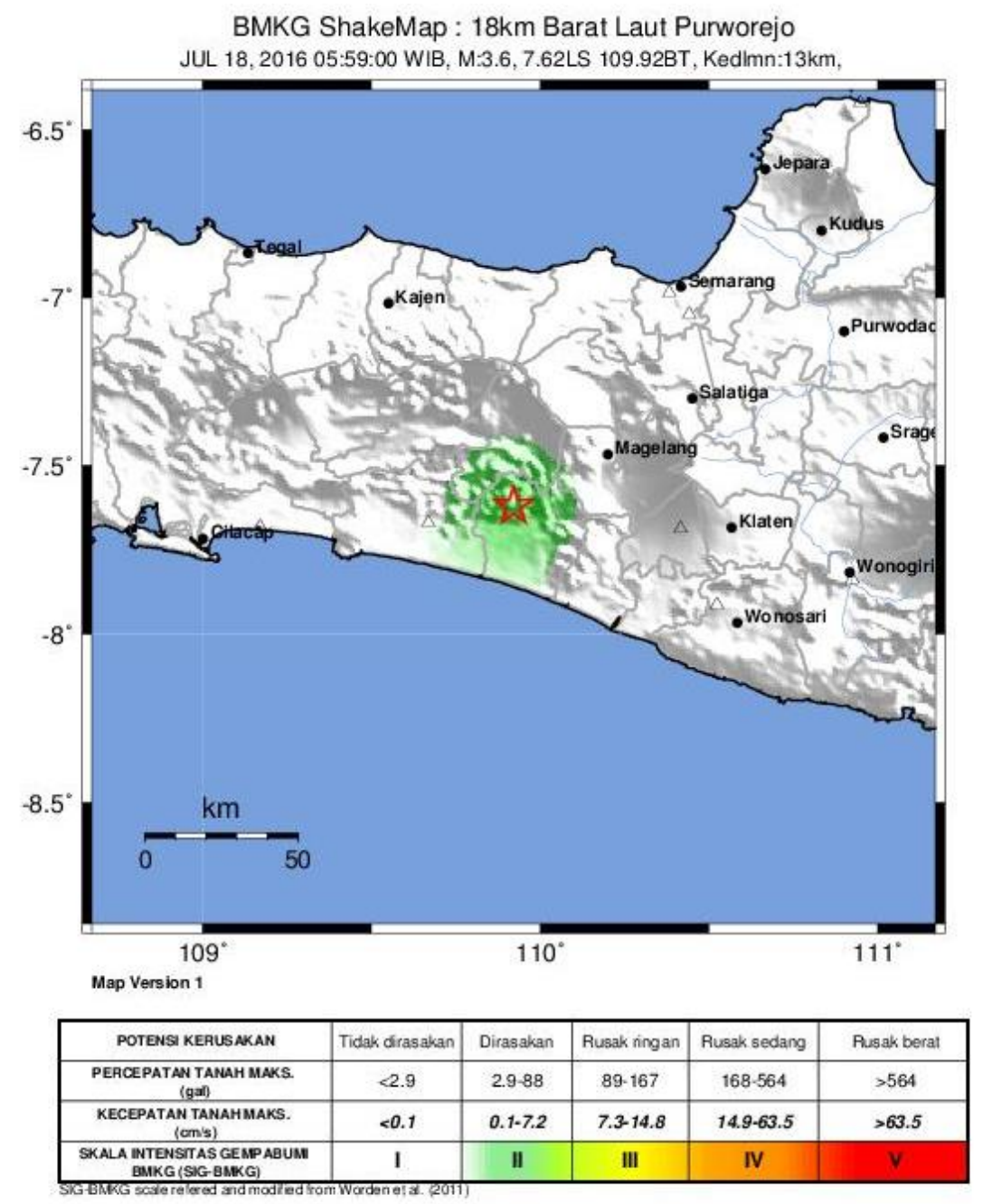

Gambar 4. (color online) Shakemap gempabumi Purworejo 18 Juli 2016

\section{Analisa Jenis Sesar berdasarkan Model Focal Mechanism}

Analisa jenis sesar penyebab gembapbumi Purworejo menggunakan data hasil rekaman seismograph jaringan BMKG dengan sistem Seiscomp3. Event gempabumi tersebut terekam pada 7stasiun seismograph, yaitu YOGI, UGM, SMRI, WOJI, SWJI, GRJI dan CNJI seperti terdapat pada Tabel 2. 
Tabel 3. Impuls Awal Gelombang P pada Stasiun Perekam Gempabumi Purworejo

\begin{tabular}{cccc}
\hline No. & Kode Stasiun & Lokasi & Impuls Awal Gel P \\
\hline 1 & YOGI & Yogyakarta & -1 (dilatasi) \\
\hline 2 & UGM & Wanagama UGM DIY & -1 (dilatasi) \\
\hline 3 & SMRI & Semarang Jawa Tengah & 1 (kompresi) \\
\hline 4 & WOJI & Wonogiri, Jawa Tengah & 1 (kompresi) \\
\hline 5 & SWJI & Sawahan Jawa Timur & 1 (kompresi) \\
\hline 6 & GRJI & Gresik, Jawa Timur & 1(kompresi) \\
\hline 7 & CNJI & Cibinong, Jawa Barat & -1 (dilatasi) \\
\hline
\end{tabular}

Sumber: Seiscomp3, BMKG

Pembacaan impuls awal gelombng $\mathrm{P}$ menunjukkan, impuls awal berupa dilatasi terjadi pada stasiun YOGI, UGM, dan CNJI. Sedangkan stasiun SMRI, WOJI, SWJI dan GRJI memiliki impuls awal P berupa kompresi. Hasil ploting impuls awal gelombang P pada bola focal, distribusi sumbu kompresi (up atau T) terkonsentrasi di pusat bola fokus. Sedangkang distribusi sumbu dilatasi (down atau P) berada di sisi barat dan timur bola fokus. Hasil model pada nodal 1 diperoleh strike 321, dip 33 dan rake 95, sedangkan nodal 2 diperoleh strike 135, dip 57 dan rake 87. Berdasarkan model distribusi sumbu kompresi (up atau T) dan dilatasi (down atau P), jenis sesar tersebut berupa sesar naik. Gambar 3, menunjukkan model focal mechanism dan parameternya. Episenter gempabumi Purworejo berdasarkan peta geologi berkorelasi dengan keberadaan sesar Rembung.

a)

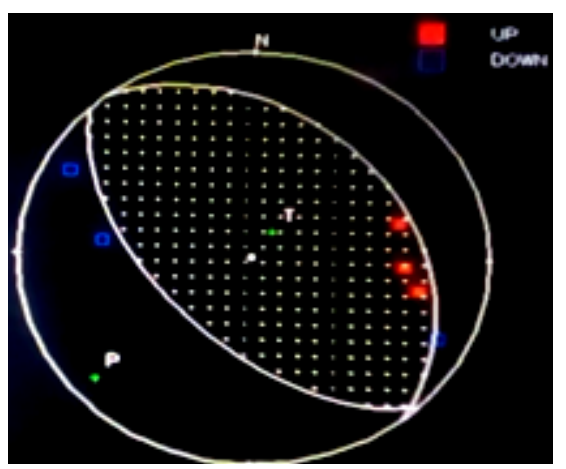

Nodal 1

STRIKE 321

DIP 33

RAKE 95

Nodal 2

STRIKE 135

DIP $\quad 57$

RAKE $\quad 87$

b)
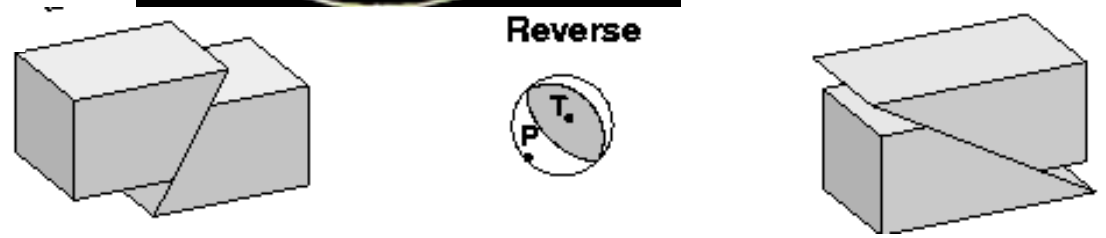

Gambar 5.a) Bola fokus model focal mechanism dan b) Visual model bidang sesar naik ${ }^{[2]}$ 


\section{KESIMPULAN}

1. Nilai PGA gempabumi Purworejo tertinggi di Stasiun KBJN yaitu 0.5075 gal (komponen EW), 0.5018 gal (komponen NS) dan 0.3538 gal (komponen UD).

2. Model shakemap menunjukkan gempabumi Purworejo dirasakan I SIG (I-II MMI) di Purworejo, sebagian Kebumen dan Banjarnegara.

3. Hasil model focal mechanismpada nodal 1 diperoleh strike 321, dip 33 dan rake 95, sedangkan nodal 2 diperoleh strike 135, dip 57 dan rake 87. Berdasarkan model distribusi sumbu kompresi (up atau T) dan dilatasi (down atau P), jenis sesar tersebut berupa sesar naik.

4. Episenter gempabumi Purworejo berkorelasi dengan keberadaan Sesar Rebung di Purworejo.

\section{DAFTAR PUSTAKA}

1 Ibrahim, Gunawan dan Subardjo.2005, Pengetahuan Seismologi, Badan Meteorologi dan Geofisika, Jakarta.

2 Focal Mechanism, diakses dari http://earthquake.usgs.gov/learn/topics/beachball.php. pada tanggal 5 September 2016.

3 Kirbani, dkk. 2006. Percepatan Getaran Tanah Maksimum Daerah Istimewa Yogyakarta 1943-2006. Jurnal Geofisika 19.

4 Munro Kim.2016. Automatic event detection and picking of $P$-wave arrivals. CREWES Research Report.Vol. 16 p1-10

5 Susanti Dwi B, dkk. Skala Intensitas Gempabumi MMI (Modified Mercalli Intensity) dan SIG BMKG.Informasi Geofisika. Stasiun Geofisika Yogyakarta.Edisi Juni Tahun 2016. Hal 9-11.

6 Wibowo, N. B.Sembri, J. 2016 Analisis Peak Ground Acceleration (PGA) dan Intensitas Gempabumi berdasarkan Data Gempabumi Terasa Tahun 1981 - 2014 di Kabupaten Bantul Yogyakarta, Vol.6, No.1, Hal. 65-72.

7 Worden Bruce C, Wald D. Shakemap Manual Release.2016. diakses dari http://usgs.github.io/shakemap/tg_processing.htm\#equation-equation2.Pada tanggal 5 September 2016

8 Zawawi A.2011.Analisa Mekanisme Pusat Gempabumi di Cilacap Jawa Tengah pada Tanggal 4 April 2011.Fakultas Saintek. UIN Syarif Hidayatullah, Jakarta. 